November 2003 - NREL/CP-500-35058

\title{
Baseline Results and Future Plans for the NREL Controls Advanced Research Turbine
}

\section{Preprint}

L.J. Fingersh and K.E. Johnson

To be presented at the $23^{\text {rd }}$ ASME Wind Energy Symposium

Reno, Nevada

January 5-8, 2004

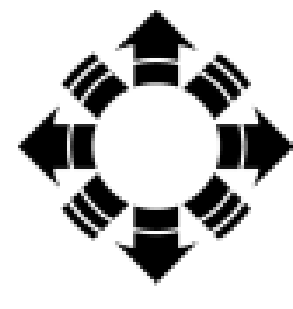

\section{NPEI}

National Renewable Energy Laboratory

1617 Cole Boulevard

Golden, Colorado 80401-3393

NREL is a U.S. Department of Energy Laboratory

Operated by Midwest Research Institute $\bullet$ Battelle $\bullet$ Bechtel

Contract No. DE-AC36-99-G010337 


\section{NOTICE}

The submitted manuscript has been offered by an employee of the Midwest Research Institute (MRI), a contractor of the US Government under Contract No. DE-AC36-99G010337. Accordingly, the US Government and MRI retain a nonexclusive royalty-free license to publish or reproduce the published form of this contribution, or allow others to do so, for US Government purposes.

This report was prepared as an account of work sponsored by an agency of the United States government. Neither the United States government nor any agency thereof, nor any of their employees, makes any warranty, express or implied, or assumes any legal liability or responsibility for the accuracy, completeness, or usefulness of any information, apparatus, product, or process disclosed, or represents that its use would not infringe privately owned rights. Reference herein to any specific commercial product, process, or service by trade name, trademark, manufacturer, or otherwise does not necessarily constitute or imply its endorsement, recommendation, or favoring by the United States government or any agency thereof. The views and opinions of authors expressed herein do not necessarily state or reflect those of the United States government or any agency thereof.

Available electronically at http://www.osti.gov/bridge

Available for a processing fee to U.S. Department of Energy and its contractors, in paper, from:

U.S. Department of Energy

Office of Scientific and Technical Information

P.O. Box 62

Oak Ridge, TN 37831-0062

phone: 865.576.8401

fax: 865.576.5728

email: reports@adonis.osti.gov

Available for sale to the public, in paper, from:

U.S. Department of Commerce

National Technical Information Service

5285 Port Royal Road

Springfield, VA 22161

phone: 800.553 .6847

fax: 703.605.6900

email: orders@ntis.fedworld.gov

online ordering: http://www.ntis.gov/ordering.htm

Printed on paper containing at least $50 \%$ wastepaper, including $20 \%$ postconsumer waste 


\section{Baseline Results and Future Plans for the NREL Controls Advanced Research Turbine}

Lee Jay Fingersh, Kathryn E. Johnson

lee_fingersh@nrel.gov, kathryn_johnson@nrel.gov

National Renewable Energy Laboratory

National Wind Technology Center

1617 Cole Blvd., Golden, MS 3811, Colorado 80401

\begin{abstract}
The National Renewable Energy Laboratory (NREL) has commissioned a highly modified Westinghouse 600 $\mathrm{kW}$ wind turbine as its Controls Advanced Research Turbine (CART). The capabilities of the original turbine have been increased through the installation of a high-speed data-acquisition and control system, a widebandwidth variable-speed generation system, and a high-speed independent blade pitch system. This turbine's purpose is to field-validate new control paradigms developed by NREL, universities, and industry and to provide data to validate new codes that have been developed for controls design.

Testing on the turbine began in late 2001, and baseline data were collected during the $2001-2002$ wind season. During this time, the turbine was operated in both constant and variable-speed modes. Baseline performance and loads data are presented here. Results indicate that the new turbine systems are performing well and sufficient data have been collected so that comparisons to more sophisticated control algorithms can be conducted.
\end{abstract}

During the 2002 - 2003 wind season, several new algorithms were tested on the turbine. These include an "Optimally Tracking Rotor" algorithm proposed before, an adaptive power tracking algorithm and several fullstate feedback systems. General results from these algorithms are presented here with detailed results presented elsewhere.

\section{$\underline{\text { TEST BED }}$}

The test bed turbine for this project is called the Controls Advanced Research Turbine or "CART" (Figure 1). This 2-bladed, upwind Westinghouse 600 $\mathrm{kW}$ wind turbine began its life at Kahuku on the island of Oahu in Hawaii and was moved to the National Wind Technology Center in 1996. Its primary purpose is to enable the field-testing and evaluation of advanced control paradigms. To accomplish this purpose, it had to be extensively modified.

This is declared a work of the U.S. Government and is not subject to copyright protection in the United States.

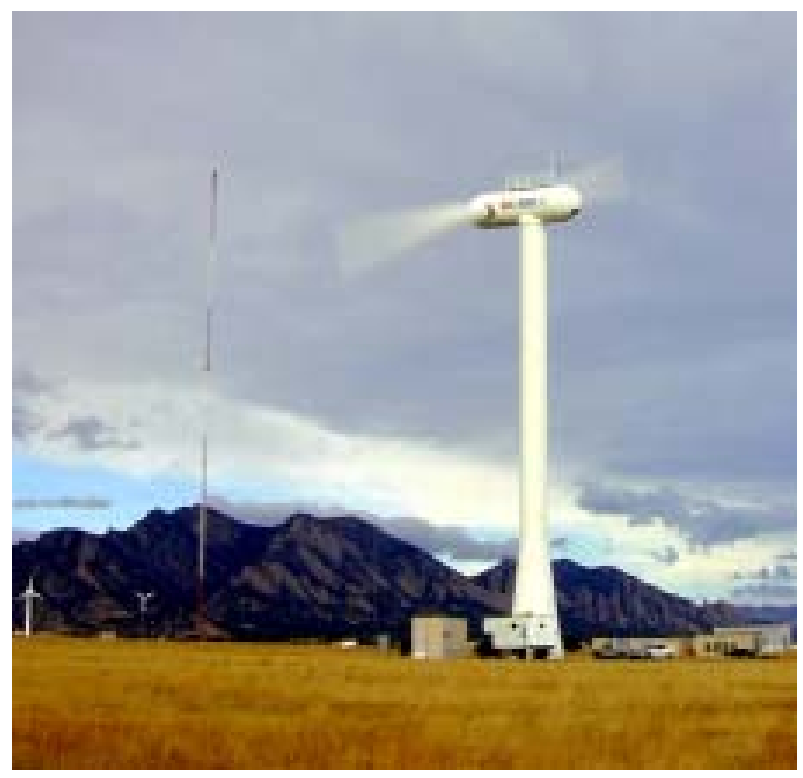

Figure 1 - Controls Advanced Research Turbine in operation at the National Wind Technology Center.

Modifications to the turbine included replacing the stock synchronous generator and fluid coupling with a squirrel cage induction machine and full power electronics set. This new system has the capability to control torque from minus rated (motoring) to plus rated (generating) at any speed. The torque loop has a very high rated bandwidth of 500 radians per second.

The original Westinghouse machine used a rotating hydraulic system to provide pitch control. Because this system proved to be very slow and unreliable, it was replaced with a high-speed electro-mechanical system composed of low-inertia electric servo motors connected to a large bull gear through a gearbox. The system is capable of pitching the blades independently at over $19^{\circ}$ per second with pitch accelerations exceeding $150^{\circ}$ per second per second.

Instrumentation on the machine includes a full complement of instruments that gather upwind meteorological data at four heights, temperature data at two heights, and a sonic anemometer. Blade root flap and edge strain gauges, tower bending gauges, a lowspeed shaft torque transducer, and a high-speed shaft 
torque transducer gather loads data. Two nacellemounted tri-axial accelerometers and a front-bearing mounted inertial motion unit that includes three accelerometers and three rate gyros complement the strain gauges. Absolute position encoders gather position data on pitch, yaw, low-speed shaft, and highspeed shaft. By measuring both low-speed and highspeed shaft positions, it is possible to directly measure shaft torsional deflection.

All of this data is sampled at $100 \mathrm{~Hz}$. A custom-built control system both collects this data and controls the turbine at a control loop cycle rate of $100 \mathrm{~Hz}$. This system is PC-based and is therefore very flexible.

\section{OPERATION}

The CART can be operated in either of two basic modes: constant-speed and variable-speed. In constantspeed operation mode, the power electronics set is bypassed and the induction generator is directly connected to the grid. In variable-speed mode, all power flows through the power electronics system.

In constant-speed mode, starts are accomplished by wind starting the machine. This means that the blades are pitched in such a way as to cause the rotor to speed up to synchronous speed. When synchronous speed is reached, rapid pitch motions are used to hold the machine at that speed until a very constrained group of conditions are met. These conditions are designed to reduce the torque and current transients that are triggered when the machine is connected to the grid. Once this connection is made, pitch is used to extract maximum power from the wind or to control this power to the rated power of the machine. Figure 2 shows an example of this type of operation.

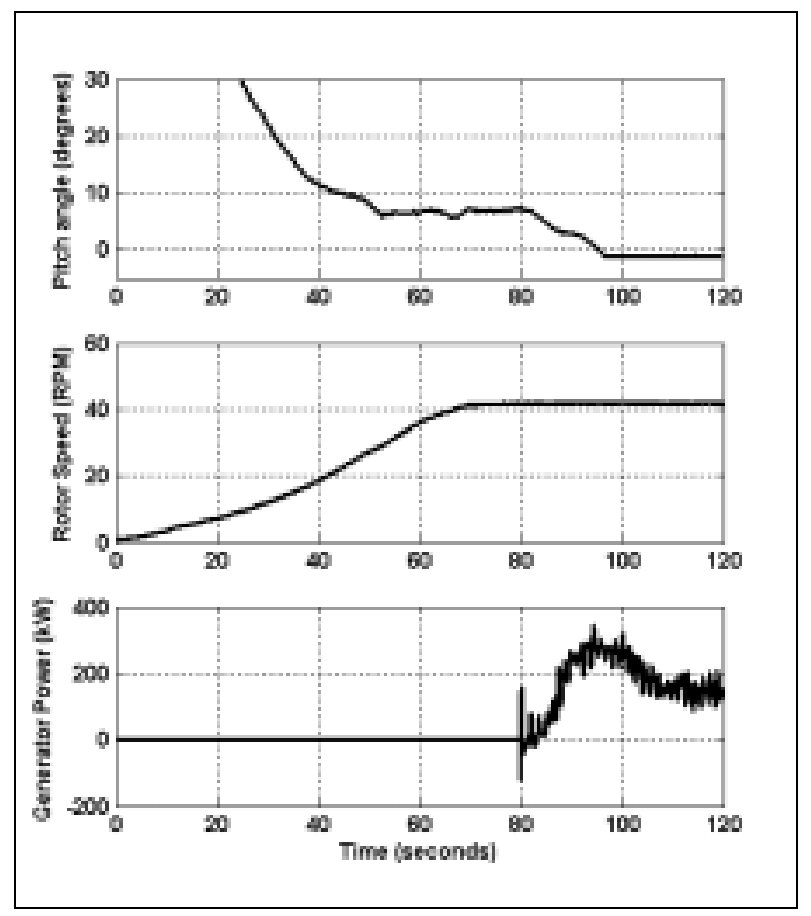

Figure 2 - Constant speed mode startup.

The wind is also used to start the machine in variablespeed mode. However, once the machine is turning, the power electronics can be brought on-line at any time. There are no torque or current transients involved with synchronizing the power electronics and so very few conditions must be met for this to occur. Once the machine is online, torque is used to control rotor speed. If sufficient wind is available, rated speed will be reached at which time torque is at its maximum value and pitch is used to control rotor speed. This torque control algorithm is shown in Figure 3.

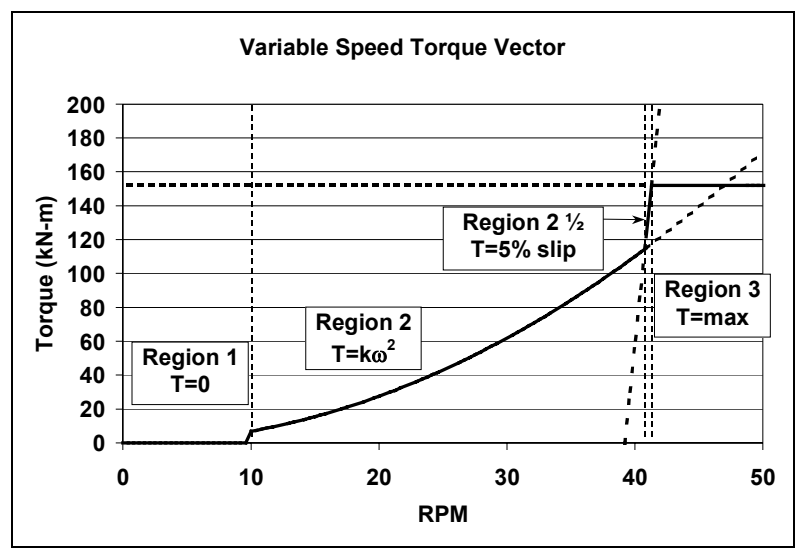

Figure 3 - Torque vector and regions for variable-speed control. 
The torque vector chart in Figure 3 includes four distinct operational modes. The first mode (region 1) is before or during startup, during which time the turbine may be rotating but no power is extracted. The second mode (region 2) is designed to keep tip-speed ratio (TSR) constant by controlling torque to a constant (more on the choice of this constant later) times rotational speed squared $\left(\mathrm{T}=\mathrm{k} \omega^{2}\right)$ [1]. The third mode (region 3) is entered when the machine reaches rated rotor speed, torque is maximum, and speed is controlled by blade pitch.

The fourth mode (region $2 \frac{1}{2}$ ) is only there because the region 2 controller does not reach rated torque at the rated speed of the machine. If region $2 \frac{1}{2}$ did not exist, the rated power of the machine would be reduced because the region 3 torque would simply be the region 2 torque when the machine hit rated speed. To ensure that the machine has the desired rated power, region 3 must have rated torque and a new region must be inserted to connect region 2 to region 3 . In the case of this turbine, these two regions are connected by a straight line with a slope that corresponds to the torque slope of an induction machine with a rated slip of $5 \%$. This relatively high slip number was chosen because it provides a soft cushion between modes that prevents excessive torque oscillations. Although rotor power coefficient $\left(\mathrm{C}_{\mathrm{p}}\right)$ is reduced in this region, the total energy lost on an annual basis is usually less than $0.5 \%$ compared with a machine in which $\mathrm{T}=\mathrm{k} \omega^{2}$ could be maintained all the way to region 3 . Figure 4 shows an example of variable-speed turbine operation through these modes.

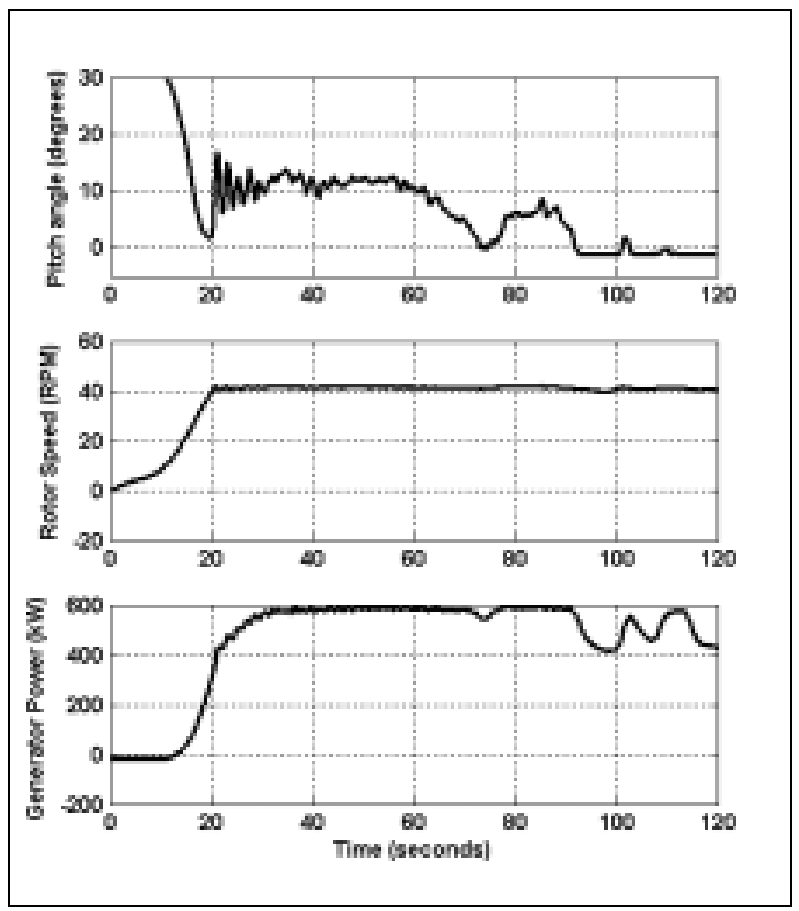

Figure 4 - Variable-speed startup and operation in regions $2,2 \frac{1}{2}$, and 3 .

In either constant-speed or variable-speed control modes, more sophisticated algorithms can be employed to control blade pitch in such a way as to reduce loads [2] or improve energy capture [1, 3]. In variable-speed mode, torque control can also be employed for the same purposes $[1,2,3]$.

\section{DATA COLLECTION}

During the 2001 - 2002 wind season, at least 50 hours of data were collected in each of the two basic operating modes, constant-speed and variable-speed. During the 2002 - 2003 wind season, more than 50 hours of data were collected in two more modes, optimally tracking rotor [1] (OTR) and adaptive control [3]. Additionally, smaller amounts of data were collected in two additional modes. The first mode is designed to use torque to avoid a tower resonance mode at which rotor 2 per revolution (2-P) interacts with the tower's first natural frequency. The second is designed to use fullstate feedback to reduce blade and/or tower loads [2].

\section{DATA ANALYSIS}

\section{Constant-Speed and Variable-Speed}

The baseline mechanical power curves for the two basic modes are plotted in Figure 5 with each point representing a 10-minute average. As can be seen in the figure, for wind speeds above $8 \mathrm{~m} / \mathrm{s}$, the constant-speed 
power curve is higher than the variable-speed power curve. This is curious because variable-speed operation should, in theory, provide the rotor the ability to run at the peak of the $C_{p}$-TSR curve at all wind speeds below rated power.

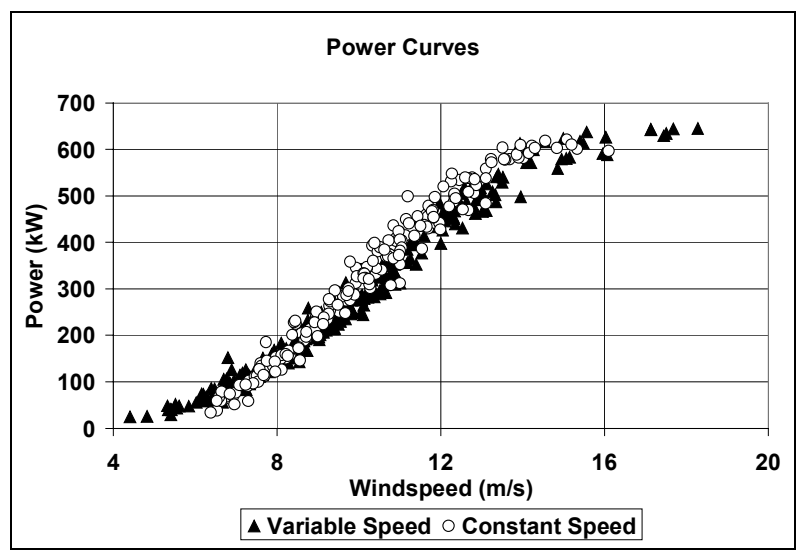

Figure 5 - Baseline mechanical power curves.

The reason for this discrepancy is shown in Figure 6. The predicted $C_{p}$ curve and the actual measured curve are quite different. Since the constant $\left(\mathrm{k}\right.$ in $\left.\mathrm{T}=\mathrm{k} \omega^{2}\right)$ was derived from the predicted curve, $\mathrm{k}$ did not match the actual rotor performance and the rotor was therefore not being properly controlled to the correct tip-speed-ratio. The result of this sub optimal operation is a reduced power curve. Energy losses from this type of error can be dramatic as was shown in [1].

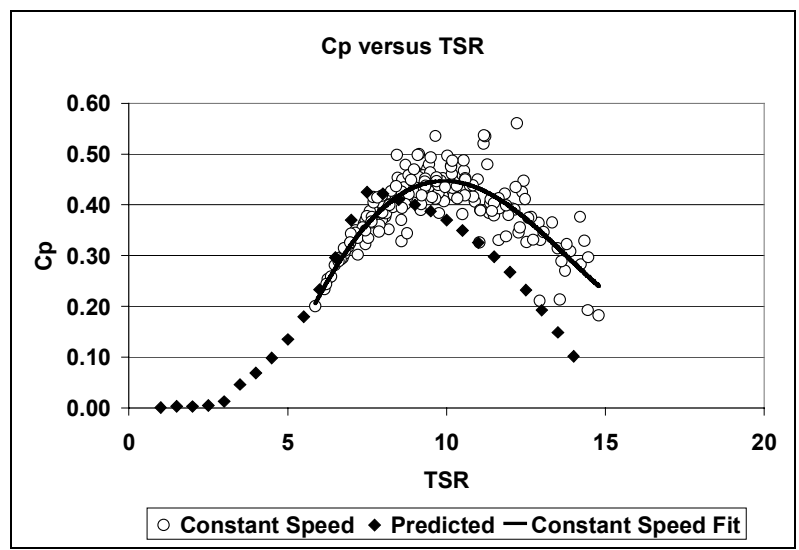

Figure $6-C_{p}$ - TSR curves, power limited to rated.

\section{Adaptive Control}

There are essentially two ways to avoid this problem. One is to avoid relying on predictions and use actual measured $C_{p}$ curves to derive the value of $k$. This is a tedious and sometimes impossible process because many variable-speed turbines are not capable of operating in a constant-speed mode. Additionally, turbine-to-turbine variability and changes in rotor performance over time would not be accounted for using this method. The other approach is to derive an adaptive scheme that would always be seeking the correct value for $\mathrm{k}$. A thorough discussion of this approach is in [3].

\section{Optimally Tracking Rotor Control}

Even if the value of " $k$ " in the variable-speed control law is set at the perfect value, the rotor speed will not perfectly track the wind. The relatively large rotational inertia of the rotating system in a wind turbine prevents the rotor from accelerating and decelerating as quickly as the wind speed can change. This leads to energy capture losses caused by failure of the machine to operate at the peak of the $\mathrm{C}_{\mathrm{p}}$-TSR curve.

In [1], a new strategy for reducing variable-speed tracking losses was described. This method, called optimally tracking rotor control (OTR), is implemented by adding a second term to the variable-speed control law.

$$
T=k \omega^{2}-G\left(T_{\text {aero }}-k \omega^{2}\right)
$$

where

$$
T_{\text {aero }}=T_{\text {shaft }}+J \dot{\omega}
$$

The new term in the control law consists of the actual aerodynamic torque minus the torque that would be extracted by the standard variable-speed control law. This can be thought of as the "net torque" available to accelerate or decelerate the rotor. This value is then multiplied by a gain "G" and subtracted from the original control law. When the net torque is positive (at low values of TSR), the term will be negative and the control torque will be reduced. Conversely, when the net torque is negative, the torque will be increased. Both situations would lead the rotor to more rapidly approach the desired operating point.

The OTR strategy is difficult to analyze from measured turbine data. Because expected energy gains from this approach are expected to be on the order of $1 \%$, extremely accurate, long-term measurements would be required. Rather than attempting this type of experiment, a detailed analysis of simulations is provided in [3]. Figure 7 gives an example of the way the algorithm is supposed to work. When the rotor is accelerating, torque is lower than with the standard $\left(\mathrm{T}=\mathrm{k} \omega^{2}\right)$ algorithm, which helps the rotor to accelerate. Conversely, when the rotor is decelerating, torque is higher thereby helping the rotor to decelerate. 


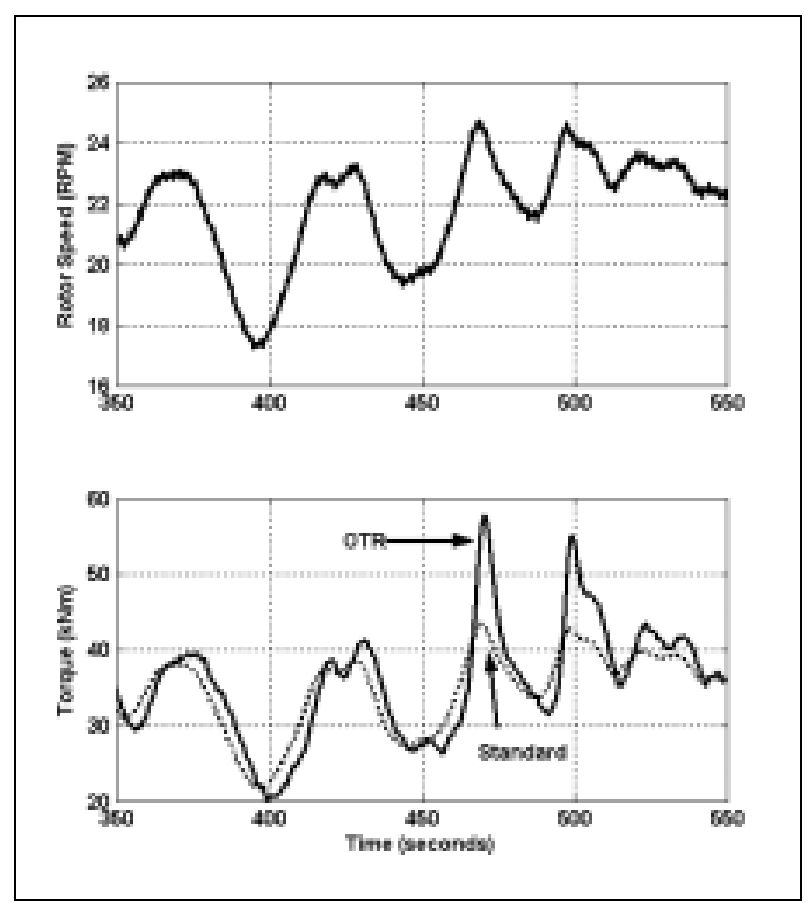

Figure 7 - Optimally tracking rotor (OTR) example. Note how OTR uses torque to help the rotor to accelerate and decelerate.

$\underline{\text { Resonance avoidance }}$

Within the normal operating speeds of the CART, rotor 2-P excitation can drive the tower at its first natural frequency. To alleviate this problem, a strategy was developed to avoid operating at a rotor speed that can cause this resonance. The tower resonance avoidance strategy employs the simple torque controller found in Figure 8. This curve is designed to multiply the standard control law (depicted as the horizontal line) to give a final torque demanded vector. As rotor speed increases, the controller is designed to prevent the rotor speed from reaching the resonance point until aerodynamic torque is sufficient to allow the rotor to run through the resonance rapidly. When speed is decreasing, the opposite strategy is employed. Speed is kept above the resonance point until aerodynamic torque has fallen sufficiently to allow the machine to apply shaft torque of sufficient magnitude to rapidly slow the machine through the resonance point.

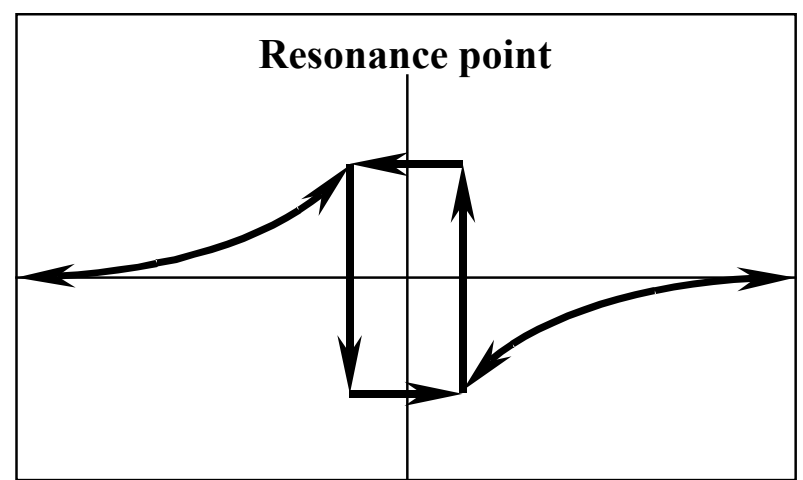

Figure 8 - Tower resonance avoidance strategy. Demanded torque with speed hysteresis is used to avoid operation at or near the resonance point.

Although this controller is quite simple, its operation has been very successful as shown in Figure 9. In this example, the wind happened to be at just the right level such that, without the resonance avoidance controller, the rotor speed would have been at or near the resonance point throughout the data segment shown. Because of the controller, this did not occur. Rather, the rotor speed was held above or below the resonance point and then forced to rapidly transition through the resonance point by a positive or negative torque excursion.

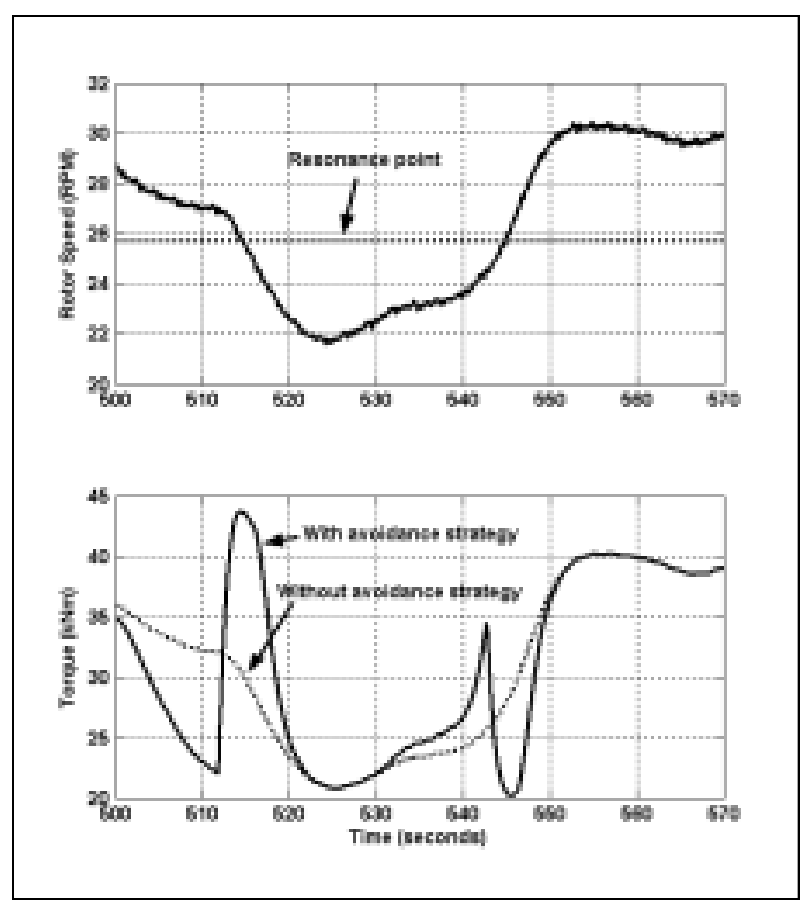

Figure 9 - Tower resonance avoidance example. Resonance is centered at 25.8 RPM. 
The primary purpose for the resonance avoidance controller is to reduce cyclic loading on the tower. Figure 10 shows a magnified view of the same section of data as in Figure 9 and a section of data from another data set. The second data set (shown on the right) did not employ the resonance avoidance strategy. Comparing the tower base bending loads between the two sets of data indicates that transitioning through the resonance quickly rather than dwelling at the resonance point greatly reduces the excitation of the tower.

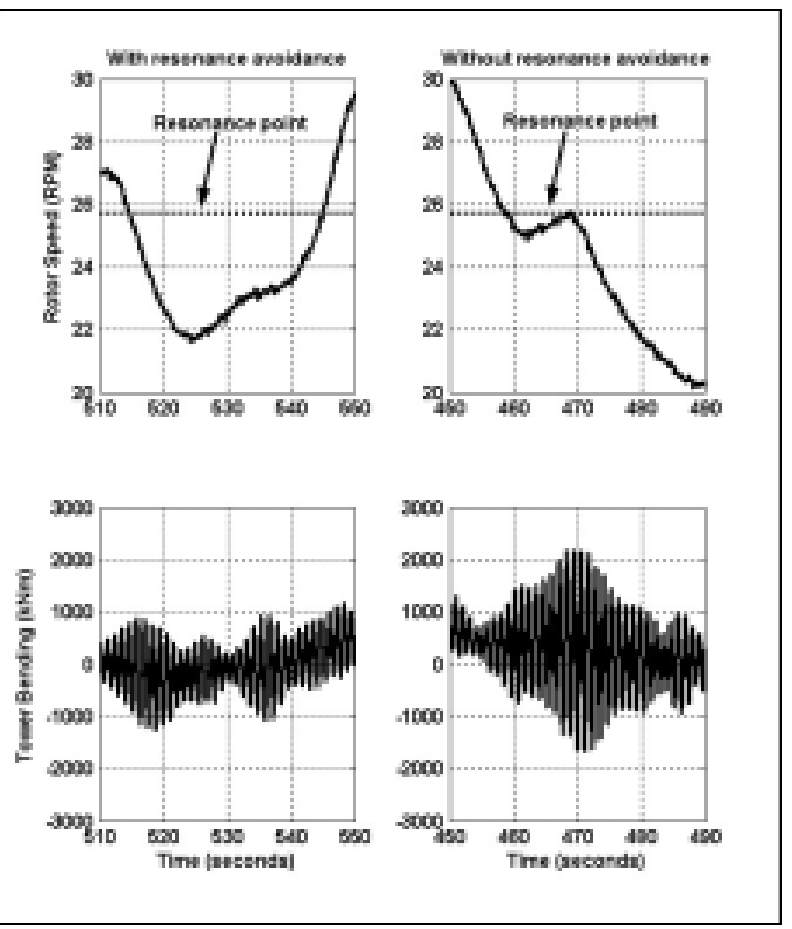

Figure 10 - Effect of resonance avoidance strategy on tower loads.

\section{Full-State Feedback}

By employing full-state feedback, it is possible to utilize many of the available turbine sensors as inputs to a controller that can be designed to perform many functions. For example, it is possible to use blade load feedback to independently control blade pitch in such a way as to reduce blade loading. Since tower fore-aft motion is largely driven by out-of-plane blade loading, tower loads may also be reduced by such a strategy.

A full analysis of this type of control is not provided here because we have not yet collected enough data to complete such an analysis. However, the controllers are working well and stable operation has been demonstrated. An example of the performance of a state-space controller is shown in Figure 11. In this example, the controller is controlling the pitch angle of each blade independently in response to blade root bending loads. For a more detailed description of this control technique, see [2].

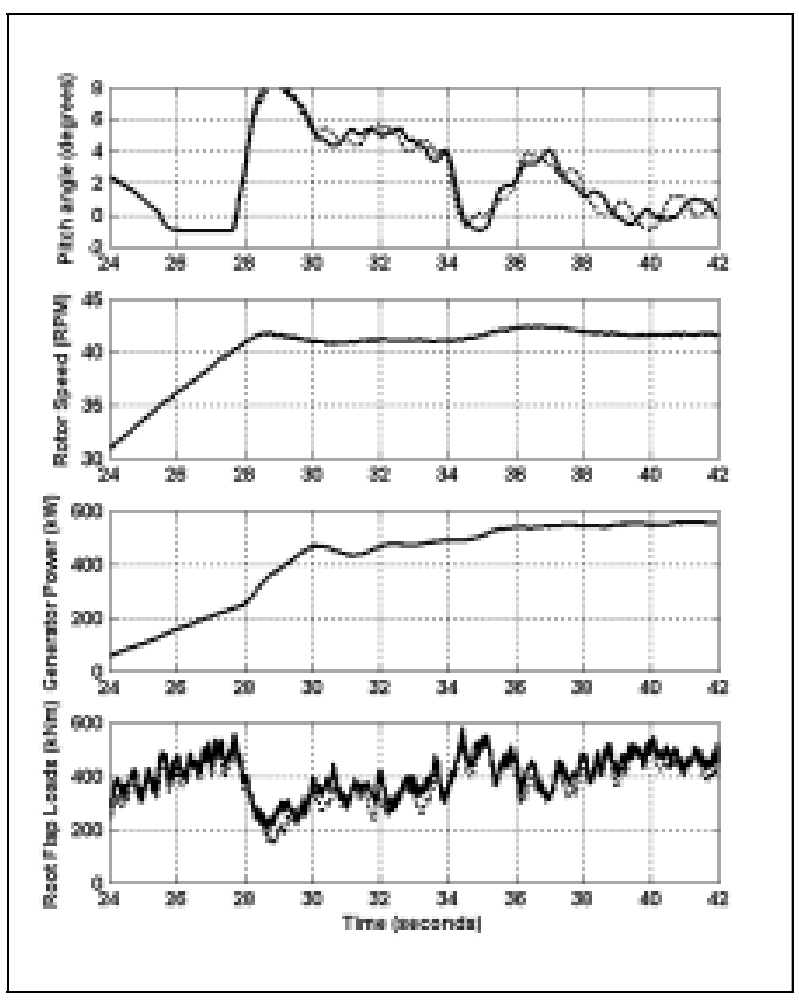

Figure 11 - Full-state feedback example. Note independent pitching in response to different blade loads.

\section{FUTURE WORK}

During the 2003 - 2004 wind season, we intend to continue testing the adaptive controller discussed in [3]. We also intend to collect larger volumes of data on the state-space controllers described in [2].

We are also acquiring a three-bladed hub and blade set for this project. This will enable us to test additional algorithms that are unique to three-bladed machines. Three-bladed and two-bladed machines possess fundamental differences that affect control design. These include symmetrical versus asymmetrical yaw inertia and lacking or possessing a teeter hinge. This new hub will either be installed on the CART or onto a nearly identical turbine a few hundred meters away. If the second option is selected, that turbine will be modified from its initial configuration in the same way as the CART. These modifications will not be difficult because many of the instrumentation modifications necessary have already been made to prepare the machine for a project called the Long-Term Inflow 
Structural Test (LIST) [4]. This project is now completed but much of the instrumentation remains on the machine or is readily available.

\section{ACKNOWLEDGMENTS}

The U. S. Department of Energy is credited for its funding of this document through the National Renewable Energy Laboratory under contract number DE-AC36-99GO10337.

\section{REFERENCES}

[1] Fingersh, L., Carlin, P., 1998, "Results from the NREL Variable-Speed Test Bed," Proceedings of the Wind Energy Symposium, Reno, NV. Reston, VA: American Institute for Aeronautics and Astronautics.

[2] Stol, K. A., Fingersh, L. J., 2004, "State-Space Control Implementation on the Controls Advanced Research Turbine (CART)" NREL/SR-500-35061. Golden, CO: National Renewable Energy Laboratory.

[3] Johnson, K., Fingersh, L., Balas, M., Pao, L., 2004, "Methods for Increasing Region 2 Power Capture on a Variable Speed HAWT." Proceedings of the Wind Energy Symposium, Reno, NV. Reston, VA: American Institute for Aeronautics and Astronautics.

[4] Kelley, N., Hand, M., Larwood, S., McKenna, E., 2002, "The NREL Large-Scale Turbine Inflow and Response Experiment - Preliminary Results." Proceedings of the Wind Energy Symposium, Reno, NV. Reston, VA: American Institute for Aeronautics and Astronautics.

[5] Carlin, P., 1997, "Some Analytic Expressions for Upper Limits on the Mean Annual Wind Turbine Power in a Rayleigh Wind Regime." Proceedings of the Wind Energy Symposium, Reno, NV. Reston, VA: American Institute for Aeronautics and Astronautics.

[6] Carlin, P., Fingersh, L., 1997, "Some Preliminary Results from the NWTC Direct-Drive, Variable-Speed Test Bed." Proceedings of the Wind Energy Symposium, Reno, NV. Reston, VA: American Institute for Aeronautics and Astronautics.

[7] Fingersh, L., Robinson, M., 1997, "The Effects of Variable Speed and Drive Train Component Efficiencies on Wind Turbine Energy Capture." Proceedings of the Wind Energy Symposium, Reno, NV. Reston, VA: American Institute for Aeronautics and Astronautics.

[8] Fingersh, L., Johnson, K., 2002, "Controls Advanced Research Turbine (CART) Commissioning and Baseline Data Collection.” NREL/TP-500-32879. Golden, CO: National Renewable Energy Laboratory. 


\section{REPORT DOCUMENTATION PAGE}

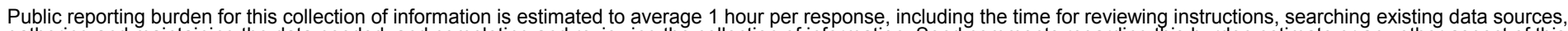

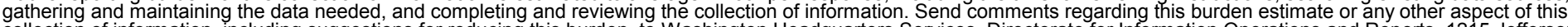

, Washington Headquarters Services, Directorate for Information Operations and Reports, 1215 Jefferson

Davis Highway, Suite 1204, Arlington, VA 22202-4302, and to the Office of Management and Budget, Paperwork Reduction Project (0704-0188), Washington, DC 20503.

\begin{tabular}{|l|l|l|} 
1. AGENCY USE ONLY (Leave blank) & $\begin{array}{l}\text { 2. REPORT DATE } \\
\text { November } 2003\end{array}$ & $\begin{array}{l}\text { 3. REPORT TYPE AND DATES COVERED } \\
\text { Conference Paper }\end{array}$
\end{tabular}

4. TITLE AND SUBTITLE

Baseline Results and Future Plans for the NREL Controls Advanced Research Turbine:

Preprint

5. FUNDING NUMBERS

WER3.1930

6. $\operatorname{AUTHOR}(\mathrm{S})$

L.J. Fingersh and K.E. Johnson

7. PERFORMING ORGANIZATION NAME(S) AND ADDRESS(ES)

National Renewable Energy Laboratory

1617 Cole Blvd.

Golden, CO 80401-3393

9. SPONSORING/MONITORING AGENCY NAME(S) AND ADDRESS(ES)

8. PERFORMING ORGANIZATION

REPORT NUMBER

NREL/CP-500-35058

10. SPONSORING/MONITORING AGENCY REPORT NUMBER

11. SUPPLEMENTARY NOTES

12a. DISTRIBUTION/AVAILABILITY STATEMENT

National Technical Information Service

12b. DISTRIBUTION CODE

U.S. Department of Commerce

5285 Port Royal Road

Springfield, VA 22161

13. ABSTRACT (Maximum 200 words)

During the 2002 - 2003 wind season, several new algorithms were tested on the Controls Advanced Research Turbine (CART) at the National Renewable Energy Laboratory. These include an "Optimally Tracking Rotor" algorithm proposed before, an adaptive power tracking algorithm and several full-state feedback systems. General results from these algorithms are presented here with detailed results presented elsewhere.

14. SUBJECT TERMS

wind turbine; variable speed wind turbine; wind turbine control system; control algorithms; renewable energy

15. NUMBER OF PAGES

17. SECURITY CLASSIFICATION OF REPORT Unclassified
18. SECURITY CLASSIFICATION OF THIS PAGE Unclassified
19. SECURITY CLASSIFICATION OF ABSTRACT Unclassified
16. PRICE CODE

20. LIMITATION OF ABSTRACT

UL 